\title{
CONRAD, COPPOLA, AND THE PROBLEM OF HISTORY
}

\section{Charles V. Hawley}

People like to separate storytelling which is not fact from history which is fact. They do this so that they know what to believe and what not to believe. This is very curious. How is it that no one will believe that the whale swallowed Jonah, when every day Jonah is swallowing the whale? I can see them now, stuffing down the fishiest of fish tales, and why? Because it is history. Knowing what to believe had its advantages. It built an empire and kept people where they belonged...

So the past, because it is past, is only malleable where once it was flexible. Once it could change its mind, now it can only undergo change. The lens can be tinted, tilted, smashed. What matters is that order is seen to prevail .... and if we are eighteenth century gentlemen, drawing down the blinds as our coach jumbles over the Alps, we have to know that we are doing, pretending an order that doesn't exist, to make a security that cannot exist.

Jeanette Winterson, Oranges Are Not The Only Fruit ${ }^{1}$

Joseph Conrad's Heart of Darkness (1902) and Francis Ford Coppola's Apocalypse Now (1979) both confront the issue of "history." Each work is in part a meditation on "civilized" societies' need for history-be that society Victorian Europe or Cold War America. Conrad's novella and Coppola's film critique the necessity for a dominant society to perpetuate, indeed spread, a particular history in order to justify not only its dominance but to rationalize its own existence. For both novelist and film director, the "horror" that destroys Kurtz is the "horror" found in the chaos beyond history. Both Conrad and Coppola exhibit discomfort with the deployment of history, but to different degrees they reaffirm history's purpose.

Historian Warren Susman describes "history" as part of "a special kind of social and cultural organization" with "myth."2 According to Susman, myth is a utopian concept utilized by societies to "explain" all. However, myth lacks the 
dynamic for change; myth exists to perpetuate a certain type of social order. History, on the other hand, functions in societies to change social order in which "the social order itself must be rationalized; reasoned explanations are called for" (8). Susman claims that "history seems able to point the direction in which a dynamic society is moving" (8). Additionally, Susman asserts that:

\begin{abstract}
Myth traditionally provides the central drama of any social order ... But history offers something vastly different in its ideal form. Since it is concerned with change, movement, the ongoing course of action and ideas, since it is more clearly related to the dynamic aspects of social life, it provides what I have called an ideology as distinguished from a utopian vision. But the two frequently work hand in hand: myth provides the drama and history puts the show on the road. Myths often propose fundamental goals; history often defines and illuminates basic processes in achieving goals. (9)
\end{abstract}

History, Susman argues, is the means by which the mythic goals of a society are accomplished; in other words, history enables societies to understand change and "progress."

Susman defines history in terms of the internal workings of a society or culture. History is essential for a society as it shifts, for example, from feudalism to industrial capitalism because history explains and justifies that societal shift. I wish to expand Susman's assessment of the necessity and function of history. History functions not only temporally within a society, as a society attempts to advance internally, but spatially, as a society attempts to expand beyond its borders into other societies or domains. Examples of this understanding of history's function may be found in the imperialistic expansionism of Conrad's Europeans or in the ideological ("democratic") militarism of Coppola's Americans.

As late-nineteenth century Europeans sought out new colonies in Africa and late-twentieth century Americans attempted to claim Vietnam in the name of "Western democracy," each society legitimized its action through and by the employment of history. Conrad and Coppola explore the nature of this employment in their respective works. Their explorations, however, are not focused on defining the particular histories employed - the history of European colonialism or American militarism-though each work does define such histories. The questions they posit address larger issues of history: why is history important? what are the limits of history? and what happens when history is discarded?

From the outset of the narrative in Heart of Darkness, Conrad invokes the importance of myth and history to the citizens of Victorian England. The unidentified narrator who frames the novella begins by evoking the past as a prelude to Marlow's story:

[The Thames] had known and served all the men of whom the nation is proud. ... It had borne all the ships whose names are like jewels flashing in the night of time... It had known the ships and the men. They had sailed from Deptford, from Greenwich, from Erith-the adventurers and the settlers; kings' ships and the ships of men on Change; captains, admirals, the dark "interlopers" of the Eastern trade, and the commissioned "generals" of East India Fleets.... What greatness had not floated on the ebb of that river into the mystery of an unknown earth! ${ }^{3}$ 
He concludes this short-hand history of English imperialism by stating that from the Thames flowed " $\mathrm{t}]$ he dreams of men, the seed of commonwealths, the germs of empires" (6). Thus, from the very beginning of his work, before Marlow even begins to speak, Conrad alerts us to the significance of myth and history to this particular society of English "men."

Marlow, however, makes us aware just after this declaration, that England was once a place before history. He begins to explain this by stating, "[a]nd this also... has been one of the dark places of the earth" (6). According to Marlow, England was once a "place" without a name or history. The Romans, he continues, conquered England in much the same fashion, we infer, Britons and Europeans are colonizing Africa. What permitted the Romans to justify their actions, and nineteenth-century Europeans to justify their own, is, according to Marlow, history, or an "idea":

The conquest of the earth, which mostly means taking it away from those who have a different complexion or slightly flatter noses than ourselves, it not a pretty thing when you look into it too much. What redeems it is the idea only. An idea at the back of it; not a sentimental pretense but an idea; and an unselfish belief in the ideasomething you can set up, and bow down before, and offer a sacrifice to... (9)

Marlow is anticipating, in effect, Susman's notions of myth and history. A society's actions need a justifying "idea" or history in order to act and change, especially when the action or change (colonial conquest) is on the surface "not a pretty thing." The Romans had an "idea" behind their conquering of Britain. The Europeans, in turn, have their "idea" - the benefits of imperialism-for colonizing Africa.

The "idea" Marlow describes is Susman's myth in the most basic sense of the word; the "idea" is something to worship "something you can set up and bow down before, and offer a sacrifice to," or as Susman states, to provide "the central drama of any social order" (9). Marlow's “idea” is also Susman's history, which "put[s] the show on the road." It permits and encourages Europe to expand into Africa. The "idea," Conrad implies through Marlow and the unnamed narrator, also gives a society its essential definition. England was nothing but darkness until the Romans brought its idea to English shores. Since that time English society developed its own idea or history, witnessed by the Thames which "had known and served all the men of whom the nation is proud" (5).

By the nineteenth century, an "idea" or history is shared by all of Europe. This history, according to Conrad, is capitalistic imperialism and it is represented in the novella by the Company that hires Marlow. Through his work for the Company, Marlow encounters the essential "truth" about the functioning of history. The Company, as itself and through its actions in Africa, attempts to inscribe a history, its history and Europe's history, upon that domain which is without history. Marlow's first contact with the Company in Africa is with the Company's chief accountant. Marlow has nothing but respect for this man because he maintained European civilization and myth; as Marlow describes the accountant, "in the great demoralization of the land he kept up his appearance" of the European gentleman (28). Who but the Company's chief accountant- the epitome of the 
institution which itself is the epitome of European history-would keep up "appearance" in a "demoralized" land? In fact, Marlow describes him as keeping track of the records, "making correct entries of perfectly correct transactions" (29). The accountant, and therefore, the Company, is nonplused by the "wilds" of Africa as he "makes correct entries." He is structure in a world beyond structure.

As Marlow travels up river into the heart of the Congo, he moves farther away from any semblance of the western civilization and history. He describes the African Continent as "a prehistoric earth." This is an incomprehensible place, "the night of first ages ... leaving hardly a sign —and no memories" (59). Marlow sees the native inhabitants as "prehistoric" men who still belong "to the beginnings of time" and having "no inherited experience to teach them" (68). Marlow is a witness to one society's attempt to impose history, its history, on another. His journey, in a sense, is a journey of discovery-to discover how successful such an imposition can and should be. Not only does Marlow discover the difficulty found in such an imposition, but he learns what happens when history is evacuated (when history, in other words, cannot be constructed and sustained). Marlow discovers all this when he reaches Kurtz's compound.

Kurtz is the quintessential representative of the Company. According to the Company's chief accountant, Kurtz is a "remarkable man" who will go far in the Company (29). "All Europe contributed to the making of Kurtz," asserts Marlow (83). However, when Marlow finally encounters Kurtz, he does not find the paragon of European society. Whatever the chief accountant thought was "remarkable" about Kurtz in the way the chief accountant envisioned him is gone. Kurtz is a shell of a man, a cadaverous specter. Marlow describes him only as a "voice" and as a man no longer attached to the earth: "There was nothing either above or below him, and I knew it. He had kicked himself loose of the earth. Confound the man! He had kicked the very earth to pieces" (112). Kurtz, who was once synonymous with European society, is unmasked:

The wilderness had found him out early, and had taken on him a terrible vengeance for the fantastic invasion. I think it had whispered to him things about himself which he did not know, things of which he had no conception till he took counsel with this great solitude. (92)

Marlow describes the condition of a man without history - a man who surrendered to prehistory. Marlow's testimony suggests what happens when history is forsaken. The Company manager who travels to Kurtz's compound with Marlow attempts to contextualize the situation within the boundaries of the Company's myth. He refuses to see past the consequences that Kurtz's actions will have on the Company. Kurtz, as far as the manager is concerned, shows a "complete want of judgment"; Kurtz's "method" is "unsound" (105). To the manager, Kurtz has taken the employment of history in the name of the Company too far. This is not the way, he claims, the Company wants to conduct business, despite whatever profit may be had by such actions.

Marlow, however, sees beyond the immediate situation of the extreme brutality by which Kurtz conducts his ivory trade. Kurtz, according to Marlow, employs "[n]o method at all" in his conduct (105). Kurtz did not simply over-step 
the bounds of civilized practices of imperial capitalism and the lessons of history-he threw the "how-to" manual away and stopped accepting the power of history altogether. This is evidenced specifically in Kurtz's report on the Suppression of Savage Customs. Marlow describes the report as "a beautiful piece of writing" and the apotheosis of the justifying myth for European imperialism (84). The postscriptum appended to the report, however, destroys whatever significance the report has:

It was very simple, and at the end of that moving appeal to every altruistic sentiment it blazed at you, luminous and terrifying, like a flash of lightning in a serene sky: 'Exterminate all the brutes!' (84)

Despite his words in the written text, "the unbounded power of eloquence-of words - of burning noble words," Kurtz stopped believing the substance of his report. History stopped making sense. "Exterminate all the brutes" suggests both that history is powerless and that this is history carried out to its logical conclusion. Whether one accepts the explanation that Kurtz had simply gone too far, or chucked history entirely, the result, Conrad suggests, is the same: madness and/ or death of both the man-of-history and prehistoric man are the results of no history. "The horror!" about which Kurtz exclaims at his death is that of a world where societal justification, its myth and history, do not exist. The horror may also be read as the impossibility of confining other societies' histories under one taut (and taught) historical rubric. "Exterminate the brutes" because they cannot be brought under European societal bounds and because they do not easily fit the historical narrative.

The significance of history, particularly narrative history, is reinforced by the conclusion of the novella. Marlow, despite all his professions to the contrary, perpetuates the myth and history. Regardless of his pronouncements about hating the "lie," he tells lies to Kurtz's fiancee to preserve her sense of Kurtz, the man of civilization. Why? Marlow offers the justification earlier in the story: "They—the women I mean—are out of it—should be out of it. We must help them to stay in that beautiful world of their own, lest ours gets worse" (81). The myth of European society, must exist, even if it is a lie, to keep the "women's" world beautiful, and by extension, that of the European man. Marlow also "lies" to the Company executive and to Kurtz's "cousin," to whom he gives Kurtz's report without the postscriptum. The only people to whom Marlow divulges the "truth" about Kurtz's madness are the men on the Nellie-the Lawyer, the Accountant, the Director, and the narrator-men who represent the dominant society and men most likely to understand Marlow's rationale for lying. However, even in telling them about Kurtz's disintegration, Marlow also confesses to the lie he tells the fiancee and why he lies. Additionally, Marlow frames his story around the darkness out of which British society, through history, has risen.

Thus, Marlow, who has observed Kurtz and been touched by Kurtz's story cannot continue in Kurtz's path. Marlow has chosen his "nightmare" in sympathizing with Kurtz, but will not succumb to that nightmare. Marlow must perpetuate the history; history is crucial to him and, as he sees it, to the society from which he comes. Marlow concludes his narrative with this justification for lying to Kurtz's fiancee: 
It seemed to me that the house would collapse before I could escape, that the heavens would fall upon my head. But nothing happened. The heavens do not fall for such a trifle. Would they have fallen, I wonder, if I had rendered Kurtz that justice which was his due? Hadn't he said he wanted only justice? But I couldn't. I could not tell her. It would have been too dark—too dark altogether. (131)

"Trifling" as his lie might be, the heavens are prevented from falling, society continues, and darkness is kept at bay. The purpose of history is made clear.

Conrad is specific about the way history is to be perpetuated. History must exist as a narrative in "noble words"- the story must be recorded and told. Marlow cannot reveal the truth of what he has seen in Africa to Kurtz's fiancee so he "tells" a lie or story. She is reaffirmed in her conclusions (false as they are) only by Marlow's spoken words. Marlow returns Kurtz's report to the "cousin" for posterity without postscriptum for posterity. Marlow must continually tell the story - perpetuate the myth for himself. We know this because the first word out of Marlow's mouth is the conjunction "and." His story is like a looped recording we assume has played before and will play again. Finally, Marlow's story is related to us through a narrator who frames Marlow's narrative. This narrator could omit the portion of Marlow's narrative in which Marlow lies to Kurtz's fiancee. However, that story, and Marlow's rationale for lying, is preserved for the reader. In fact, the novella itself serves as a meta-narrative demonstrating history in action as Marlow's circular story is recorded for us to read continually.

Although Conrad problematizes the validity of history (capitalist imperialism) - reading him as optimistically as possible-he does underscore its necessity to the sanctity of a dominant society. Coppola's Apocalypse Now is much more cynical. His conclusion, although similar to Conrad's on the importance of history, is premised on a greater sense of danger. This danger, in turn, reflects both a shift in the medium used to convey the story and in the time period.

Unlike Conrad's novella, Coppola's film makes no secret about Kurtz's madness. We learn this at Willard's briefing for his mission at the film's outset. Patrick Chabal and Paul Joannides are critical of this scene, claiming that Coppola ruins the essence of Conrad's purpose:

Coppola, by changing the plot to one where Kurtz is known from the beginning to have gone to the bad and to have been disowned by his "film," not only evades the moral issue but eliminates the essential ingredient of tension in Conrad's story. ${ }^{4}$

In Coppola's film we know from the start that Kurtz, "a great man, a humanitarian man," has gone insane. Rather than confront us with the surprise that Kurtz has lost his mind, Coppola, through Willard, explores the reason for Kurtz's insanity. The question is not, as it is in Heart of Darkness, who is Kurtz and what happened to him? Willard suggests that "[i]t wasn't just insanity and murder, there was enough of that around for everyone." Instead, the question for Willard becomes, do I agree with my commanding officers or Kurtz?

During the briefing scenes the importance of history is made apparent. The U.S. military is the epitome of Coppola's idea of dominant society. For Conrad, the Company represented European capitalist imperialism. For Coppola, the U.S. military represents what constitutes the new dominant society, which in the 
twentieth century is Cold War U.S. society. ${ }^{5}$ The setting of the briefing is significant. Although the headquarters building - a mobile home-is in Vietnam, the room in which Willard is briefed has all the appearances of a suburban home in America, including a kitchen and muzak. The ambiance suggests the standard by which Americans live - the way of life America intends to preserve and export. The military represents the "history" that actuates the myth of the American way of life.

The general goes into great detail to explain not the importance of the myth but what happens once that myth is forsaken and history fails at achieving the goals of the myth. Like Conrad's Kurtz, Coppola's Kurtz is the apotheosis of the American historical agent. He "was" the ideal soldier. According to the general, Kurtz's methods now are "unsound"- they reflect what results once "the dark side overcomes the better angles of our nature." Kurtz's "unsound" methods, however, are not the severity of his brutality, but the extent to which he is operating without the "authority" of historical narrative, and is starting to turn against the society he was supposed to support. Kurtz is not reprimanded for conducting the unauthorized Operation Archangel. The operation is a success for the U.S. military. Instead of punishment, Kurtz is given a promotion. He is brought up on murder charges, however, for killing pro-American Vietnamese intelligence officers. In other words, without the myth, Kurtz is beginning to destroy the dominant society. He is no longer destroying the enemy "pig by pig, cow by cow" but he is intent on destroying "army after army." He is a soldier without restraint. More importantly, Kurtz states on the tape that is played for Willard at the briefing, "They lie and we have to be merciful to those who lie." Kurtz is a threat not only because of his destructive force, but because of his attempts to expose the "liars" in the U.S. military who are upholding the myth.

Willard's "mission" is essentially to help perpetuate the myth and history by terminating Kurtz's destabilizing influence. Willard, unlike Marlow, is an agent in the making and maintaining of history. $\mathrm{He}$ is a soldier sent to correct the wrongs of another soldier. If Marlow had been the Company manager his role in Conrad's story would be very different. Willard is not just the observer-turnedparticipant that Marlow is; Willard is a participant from the start. Willard's journey up the Nung River is not only an exploration of the history that is being invoked, but a perpetuator of that history. He is also directly involved in the moral implications of that history. As he states: "It was no accident I got to be caretaker of Walter E. Kurtz's memory... There is no way to tell his story without telling my own... And if his story is really a confession, so is mine." Willard's assertion is more authentic than Marlow's similar statement that Kurtz's "destiny" was "My destiny!" (119).

Willard's first encounter after the briefing is with Colonel Kilgore's air cavalry division. Kilgore, Coppola makes clear, is the American myth in action as history. The importance of history saturates these "Kilgore" scenes. Kilgore's unit is the modern-day version of the old U.S. cavalry. The reference to the cavalry is obvious with its allusions to America's military hegemony in "winning" the west. ${ }^{6}$ Coppola visually accentuates that thematic allusion. Kilgore wears a 
nineteenth-century U.S. cavalry hat. When the "First of the Ninth Air Cav" division takes off for its assault against the Viet Cong, a shot focuses on a trumpeter, also wearing a cavalry hat and playing the cavalry "charge." These seemingly absurd and hyperbolic allusions demonstrate not only the presence of history but how history is used to legitimize present action.

As Kilgore's troops are "mopping up" their assault on the Vietnamese village, Coppola presents us with visual "justifications" for the action. With Kilgore's troops comes salvation for the villagers. In one of the passing shots of the "mopup" montage an American soldier and his Vietnamese translator are addressing a crowd of villagers. They tell the Vietnamese, "[w]e are here to extend a welcoming hand." Another shot in this montage also depicts a Mass being given to the troops. The implication of this shot is that Americans not only bring with them civilizing religion, but their actions are sanctified by religion. Religious supremacy is also implied with the presence of a church, still under construction, in the background of several of these shots. In one of the shots in which the church is present, a caribou is air-lifted out of the scene. This suggests the evacuation of "primitive" religion - which is illustrated later in the film with a Cambodian village sacrifice of a caribou-from the site of American victory.

The image of the air-lifted caribou provides the transition from the battlefield scene to a scene later that night of the men relaxing. A group of soldiers are gathered around Kilgore as he strums a guitar in front of a bonfire. Kilgore, as Willard points out, has turned the landing zone into a "beach party," attempting to make Vietnam just like America or "home." The men are eating t-bone steaks. The implication here is that the caribou air-lifted out of the last scene is now being consumed by the victors. Put another way, "primitive" culture is consumed and disposed of by the dominant culture. Kilgore has managed to turn the battlefield into a victory celebration and a re-creation of the set for the classic 1960s American beach movie. Coppola underscores the beach party analogy with his emphasis on the theme of surfing. Kilgore and his men are American surfers in addition to being American soldiers. Their motivation for the next day's assault on the beach point controlled by the Viet Cong is simply put by Kilgore: "Charlie don't surf!" Only Americans, he suggests, know the worth of things, including Vietnam.

Thus Kilgore serves as the representative of the dominant society. He is in control of the myth and he is making history. Kilgore knows the value of American history because, as Willard states, "You just knew [Kilgore] wasn't going to get so much as a scratch here." He provides legitimization for American actions in Vietnam. Again Willard observes that "you felt safe" with Kilgore. Kilgore is American history in motion. He is, presumably, what Kurtz once was. Willard ponders, "If that's how Kilgore fought the war I began to wonder what they really had against Kurtz." Kurtz's "crime" is in part not being the soldier that Kilgore is. Kurtz has rejected being a role model in the dominant history.

Having been introduced to Kilgore, the archetypal U.S. soldier and purveyor of the American myth, Willard proceeds to experience what happens when the Kilgores of the world no longer "set the record straight" and one gets beyond his- 
tory. The patrol boat crew's encounter with the tiger is one such example. When Willard and Chef leave the boat in search of mangos, they confront a visual image of "prehistory." The jungle setting is dense and overgrown to an extreme degree; the trees are tremendous in size and monstrous in shape. The appearance of the place is that of some age before human time and influence. They are attacked, not by the Viet Cong, but by a tiger. Willard and Chef retreat back to the safety of the boat and the river.

Willard comments afterward on Chef's self-reproaching about leaving the boat even for such an innocuous adventure: "Never get out of the boat... absolutely, goddamn right... unless you were going all the way." The boat serves for Coppola, as it does for Conrad, as an extension of civilization. The boat provides a human-made "safe space" for Marlow and Willard. Off the boat they are without historical context. For Willard and Chef confrontation with the tiger is confrontation with prehistory or non-history (if we define prehistory as the time before human record). According to the historical narrative, both men were expecting to confront the human enemy; instead, they confront something completely unexpected and not human.

Willard meditates on the tiger incident by linking his experience with Kurtz: "Kurtz got off the boat... he split the whole fucking program." Kurtz abandoned the military and plunged himself into a realm beyond western history. Willard later remarks that had Kurtz stayed in the military he would have been made a general; however, Kurtz "went for himself instead." Again, Kurtz's crime is "splitting the whole fucking program," and as the tiger scene suggests, severing his ties to the dominant society and its myths.

As Willard journeys further up the river, he begins to echo the sentiments of Kurtz; he begins to doubt the myth of headquarters and of the military generally. Following the sampan massacre, Willard ponders, "It was a lie and the more I saw of them the more I hated lies." This statement almost parallels Kurtz's comment, "they lie and we must be merciful." Willard is growing to understand Kurtz's motivations for escaping history.

By the time he reaches the Do-long Bridge, Willard confronts the very edges of history. These edges are frayed, insane. Soldiers fight without commanding officers. They systematically rebuild a bridge-attempting to preserve society through mythic ritual- that the Viet Cong continually destroy, "just so the generals can say the road's open." The Do-long Bridge is the terrifying liminal space between history and non-history, where the rationale, the myth, is most in doubt. This is the point at which one must decide whether or not to "split the program." This is also the point Willard reads the communiqué about Colby, a man sent before Willard to terminate Kurtz. Willard reads Colby's final letter to his wife stating: "Sell the car! Sell the house! Find someone else! Forget it!" Colby passed the Do-Long Bridge, just as Willard is doing, only to be consumed by whatever consumed Kurtz. "Forget it!" the letter states emphatically. History is memory. Colby is forgetting and forsaking history. He has joined Kurtz. The question now becomes, will Willard follow suit?

When Willard finally confronts Kurtz, Kurtz's first attempt to reach Willard is 
through the use of history. Kurtz attempts to seduce Willard with an evocation of a shared past; they both grew up near Toledo along the Ohio River. Of no small consequence is the fact that Kurtz is a student of history. ${ }^{7}$ Kurtz has training as a historian, and is aware of its powers and its fallacies. Kurtz's attempts, however, to reach Willard through the shared history of Ohio childhoods are futile. Unlike the photographer and Colby, Willard is not drawn in by Kurtz's "method," sound or unsound. In fact, Willard claims, "I don't see any method at all." At this point in the film Willard is still ambivalent about what he is going to do about Kurtz.

Whatever reservations Willard has about killing Kurtz, however, are resolved after Kurtz presents Willard with Chef's head. There is no dialogue in the scene only the exchange of stares between the two men. Willard is bound and helpless. Kurtz's face is painted in terrifying camouflage. The only words uttered in this scene are by Willard as he cries in terror and remorse over Chef's severed head. Coppola's Kurtz performs an act of savagery—killing one's own-not demonstrated by Conrad's Kurtz. This is proof positive for Willard and for Kurtz that Kurtz has gone too far. From this point forward both men are preparing for Kurtz's assassination. Although Willard admits to continued doubts about executing Kurtz, it is an act that he must commit. "Everyone wanted me to do it, [Kurtz] most of all," claims Willard. Kurtz, in essence, wills his own death through Willard. According to Garrett Stewart, Kurtz is aware of his own savagery and engineers his own death:

Coppola's Kurtz knows his own evil to some degree and waits for the man who will know himself well enough in Kurtz to will the eradication of that self, someone in no position to "judge" him, who will permit him to die a "soldier's death" even at the hands of one of his own...Private and public renunciation merge... Kurtz has finally found an antagonist whose reciprocation of wicked instinct enacts on a private scale the internecine nature of the whole war. ${ }^{8}$

Kurtz knows that he has gone beyond the bounds of the dominant society. He has killed Chef, a fellow American and "soldier."

More significantly, Kurtz is intent on total destruction. Like Conrad's Kurtz, Coppola's Kurtz has compiled a written manuscript_-of what exactly we never know. Within those pages, informed by Conrad's Kurtz's postscriptum, is scrawled "Drop the Bomb!...Exterminate them all!" The imperative is directed not just against "brutes," but against "all!" The desire to use the atom bomb suggests Armageddon and total devastation. Kurtz not only suggests rejection of history, but the destruction of all history. As he demonstrates by killing Chef, Kurtz knows to what extent his destructive capabilities will take him. By willing his own death, Kurtz calls on someone capable (Willard) to put him out of the "pain" he suffers out beyond history and destroy the malice he represents to culture. "You have a right to kill me," he tells Willard.

Coppola, however, does not create Willard to be a simple tool manipulated by headquarters and Kurtz. Although Willard acknowledges that everybody, including Kurtz, wants him to eradicate Kurtz, he is no longer "in their fucking army." He also avoids being completely engulfed by Kurtz's madness. Willard kills Kurtz, but not to assume Kurtz's place in the world beyond the historical 
narrative. After killing Kurtz, Willard pauses for a moment before a worshipping mob of former Kurtz followers. However, he does not succumb to "the temptation to play god," as the general in the briefing scene accuses Kurtz of having done. Willard, instead, tosses the murder weapon aside and "gets back into the boat." Although Willard is no longer in "their fucking army," the scene suggests he still acknowledges the need for the myth of history.

Willard's complicity with history is implied by his getting back into the boat, but it is also implied by the final shot of the film. In this shot we are shown in various overlays the face of a stone idol from Kurtz's compound, Willard's face in camouflage, and the images of the helicopters depicted in the opening scene of the film. The visual allusion to Willard's face and the helicopters return us to the beginning of the film. Thus, Coppola attempts to visually recreate the repetitive loop of story-telling that is suggested in Heart of Darkness. Marlow begins his narrative with the conjunction "and" implying that the story he tells is part of a continuing narrative running in his mind. Marlow's narrative ends with the line: "It would have been too dark - too dark altogether..." These final ellipses return the reader back to Marlow's opening line beginning with the conjunction "and": "And this also ... has been one of the dark places of the earth." This circularity implies that Marlow continually tells this story either to himself or others in an effort to make sense of it.

Coppola suggests that Willard does the same thing. As Garrett Stewart points out: "Though Coppola's rhetoric at this point [the final scene of the film] is entirely visual, this notion of circularity and proleptic repetition is one he could have taken indirectly from Conrad" (472). Willard continually plays his journey to Kurtz's world over in his mind. History is significant to Willard; he retells the story, be it for therapeutic reasons, to keep his sanity. This intimates that history staves off insanity and chaos-it organizes and rationalizes events and makes them intelligible.

Coppola's film refuses to end, like the novella, with the reaffirmation of the "lies" both Willard and Marlow hate. Marlow hates the lie of history. He understands the necessity of the lie, however, and proceeds to lie to Kurtz's fiancee. Coppola's film ends much more ambiguously. We are never shown whether Willard seeks out Kurtz's son and wife to lie to them or tell them the "truth" of Kurtz's demise. Does Willard eventually subscribe to the "lie," as does Marlow, or does he eschew the lie and thereby eschew history? We never know. Coppola, through Willard's account of Kurtz's demise, suggests the "horror" invoked when one goes beyond history. However, Coppola does not provide us with the easy answer to the question "is history necessary?" For Coppola to answer "yes" to such a question would be to affirm the American history portrayed in his film. Instead, Coppola leaves us pondering Willard's next step.

If we look beyond the plot of Willard's narrative, we find Coppola resolving the question of history's purpose through the construction of the film. Garrett Stewart describes film's relation to fiction: "Film not only overhauls or reinhabits but extrapolates from a piece of classic fiction" (455). Coppola takes Conrad's meditation on history and contextualizes it within the medium of film. 
Additionally, Coppola examines history from a poststructural vantage point. By doing so Coppola answers the question of the necessity of history in much the same fashion as Conrad. Coppola's answer is a qualified "yes." On a filmic level—beyond the plot of Willard's story-Coppola shares Conrad's strategy of bringing the trajectory of the structure back around on itself; both Willard and Marlow continually retell their respective tales. This is not the only strategy Conrad employs that Coppola borrows. In fact, Coppola subordinates the power of his film as film to that of "written" narrative in several ways (the most significant being the use of voice-over narration). In doing so, he shares Conrad's position on both the nature and importance of history.

As a film, Apocalypse Now should suggest through visual construction what Conrad in Heart of Darkness is only able to communicate through words on the printed page. Coppola does this and more by "showing" us through visuals what would take pages of text to describe-or fail to describe. (How, for example, would one put into words Willard's madness in the Saigon hotel room that Coppola encapsulates visually in under 10 minutes?) The Kilgore scenes, the tiger encounter in the primeval jungle, the lunacy at the Do-long Bridge, the savagery of Kurtz's compound and Kurtz's murder are powerfully constructed visual scenes.

Despite the power of the visuals, Coppola employs "words" and literary narrative structure to unify his film. Coppola chooses film as the medium for his story. However, he deconstructs the validity of film to tell his story as much as he tries to reinforce it. The first instance of this subversion is the appearance of the television crew "documenting" Kilgore's "mop-up" activity at the Vietnamese village. As Willard lands on the beachhead he is told by the director of the camera crew to pretend that he is fighting. Not only does this scene imply the artificiality of film-making-reinforced in a later shot of Kilgore faking concern for a soldier's well-being in the presence of a press-corp photographer-but it delegitimizes film as a "realistic" representation of history and as a "realistic" method for properly telling history. Coppola refuses to use "realistic" film style-cinema verite, hand-held shots, or the incorporation of actual Vietnam documentary footage - and works within the conventions of Hollywood cinema style and production. William Hagen claims that despite Coppola's efforts to confront audiences with what Coppola perceived to be the insanity of Vietnam and their own media-generated views of the war, "viewers were all too aware that an auteur-director and... a star had control of the script and the necessary organization of technology to bring off the best lines and the most spectacular scenes." Hagen continues:

Apocalypse Now does not really attempt to document the course of the Vietnam war or even many of its typical features. If anything, it by-passes documentation to confront our media-fed memory of the war and our armchair moralism about its futility with scenes which push us to the extremes of vicarious participation... and gut level revulsion... (233)

Coppola eschews any attempt at creating "reality" through this film.

Film, then, is artificial, but is it inadequate to express the essence of history? Coppola answers this question through the character of the photographer in 
Kurtz's compound. The photographer asks Willard whether it will be the photographer who tells Kurtz's story to others, "Am I going to be the one to set things straight?" The photographer answers the question himself, "Wrong . . . its you [Willard]." The photographer with his pictures will not be able to "set things straight."Willard will have to preserve and communicate the "history." Coppola admits that pictures and visual representations are inadequate to "tell" the story. The inadequacy is also supported by the inclusion of shots of Willard looking over Kurtz's dossier. Willard must read through Kurtz's history to give the audience context. Kurtz's history, in other words, is presented through written documentation. Coppola could have simply demonstrated Kurtz's decay by showing the audience only the dossier photographs, moving from the pictures of the Kurtz the "good soldier" to the last photograph taken of him as a monstrous apparition with the "better angles of his nature" overshadowed. Instead, Willard "tells" us the details of Kurtz's achievements. He organizes Kurtz's history through words and underscores the necessity of a narrative history to "explain" Kurtz.

The significance of the written word is also emphasized at the film's conclusion. As Willard leaves Kurtz's compound he takes with him Kurtz's manuscript. The manuscript provides written evidence of Kurtz's insanity. The word has power. ${ }^{10}$ Additionally, within the manuscript are the words "exterminate them all." These words, Coppola admits, must be shown to the audience; there are no visual equivalents, or if there are any they are insufficient.

Nothing in the film, however, subverts the importance of the visual image more than Willard's voice-over narration. Why does Coppola rely on such an extensive use of spoken "words" in a film? Coppola shies away from a poststructural position by validating the importance of words to give meaning. Rather than leaving interpretation to chance, Coppola relies on non-visual narrative to structure his film. Coppola is unable to fully convey the story without "telling" it through Willard's narrative. What this suggests is that Coppola cannot sit comfortably in the ambiguity of his film's conclusion. We are never shown whether Willard "lies" - maintains the American myth of military valor and purpose-or tells the "truth" about Kurtz's madness to anyone. However, through Willard's voice over, we know that Willard is attempting to structure all that he has witnessed and done within the confines of a story or history. He is "telling" us. In this way, Coppola is reinhabiting Conrad, who also relies on a first person narrative.

Apocalypse Now would be a much different film without Willard's guiding voice. The film would be less comprehensible and a more potent condemnation of history as structuring. The film would no longer be Willard's confession or history. Coppola is on one level affirming his historical moment of post-Vietnam and post-Watergate America which questions belief in myth and history. With Willard's narration, however, the film confirms history. Willard's narrative confines Kurtz's insanity within a structured story-a story the film's opening and closing suggest to us is ritualistically told again and again.

Both Conrad and Coppola critique the purpose of history in their respective works. Conrad, although acknowledging the component of the "lie" in history, reinforces the necessity of history to give order to a society. Coppola, echoes the 
same sentiment. On the "literal" level (through the story we are shown) the film exposes the failure of history-Kilgore is not presented in a positive light nor is the perpetual rebuilding of the Do-long Bridge - and the insanity of prehistoryKurtz is a lunatic. We never know what Willard does at the film's conclusion. Coppola demonstrates his ambivalence about myth and history. To use history (Kilgore) is pernicious, but to forsake history (Kurtz) is insanity. Apocalypse Now also reflects the poststructuralist age in which it was made; words and images have no fixed meaning, therefore narratives composed of words and images are equally indeterminate. History can have no essential "truth." Is Kurtz a madman or a prophet? Through Willard's actions, and given the images we see around Willard (Kilgore and Do-long), we are not certain. Coppola casts doubts on the validity of history as structuring and legitimizing.

On a filmic level, however, Coppola reaffirms the necessity of history as much as he renders it suspect. Willard's voice over, Willard's reclaiming of Kurtz's manuscript, and the focus on Kurtz's dossier, all underscore the importance of narrative, words, and, finally, history. Coppola presents us with a spoken narrative, illustrated to extreme degrees by visual images. The film ruminates on what happens to society with a wrong-minded history, but it also points a wary finger in the direction society would head without some type of organizing myth or history. In Apocalypse Now, Coppola presents us with a similar discussion of history that Conrad presents in Heart of Darkness, but there is much more at stake in Coppola's film. Not only is the legitimacy of history at issue, but the validity of narrative itself is in question. Coppola suggests that in the late twentieth century (the nuclear age) the imperative "exterminate them all" is not impossible; he warns us that the demise of narrative, history, and, conceivably, societal order is a potential reality. Coppola may hate the "substance" of this particular history, but maintains that the "form" of history is necessary. After all, Willard lives to tell the tale.

\section{Notes}

\footnotetext{
'Jeanette Winterson, Oranges Are Not The Only Fruit (New York: The Atlantic Monthly Press, 1985) 94-95.

${ }^{2}$ Warren Susman, Culture as History: The Transformation of American Society in the Twentieth Century (New York: Pantheon Books, 1984) 8.

${ }^{3}$ Joseph Conrad, Heart of Darkness and The Secret Sharer (New York: Bantam Books, 1981) 5-6.

${ }^{4}$ Patrick Chabal and Paul Joannides, "Copping out with Coppola," The Cambridge Quarterly 8 (1983): 192.

${ }^{5}$ Coppola does not ignore the differences between 19th century imperialism and Cold War American imperialism. Kurtz refers to the U.S. military command as "nabobs"linking them with 19th century British imperialism in India. There are also references in the film to capitalism and commerce. These references are collapsed with the discourse on the military. Willard describes Kurtz, a one time model U.S. soldier, as "being groomed for a top spot in the corporation." Kurtz also refers to Willard as "an errand boy sent by grocery clerks to collect a bill." Coppola simplifies the complexity of the Cold War struggle, which is no longer a search for new markets, to that of military conquest or superiority.
} 
${ }^{6}$ The use of the "cavalry" also has a long tradition in American cinema. According to Richard Slotkin: "These films retained the essential elements of Ford's original myth: the use of the cavalry as a microcosm of embattled American values." Richard Slotkin, Gunfighter Nation: The Myth of the Frontier in 20th Century America (New York: Antheneum, 1992) 365. Slotkin also asserts: "The cavalry film tended to remain responsive primarily to Cold War issues." Slotkin 377, 334-335.

${ }^{7}$ According to his dossier-his c.v. is displayed in the scene in which Willard is first remarking on Kurtz's academic and professional achievements-Kurtz received a Master's degree in history from Harvard.

${ }^{8}$ Garrett Stewart, "Coppola's Conrad: The Repetitions of Complicity," Critical Inquiry 7 (Spring 1981): 469.

"William M. Hagen, “Apocalypse Now (1979): Joseph Conrad and the Television War," in Hollywood as Historian: American Film in a Cultural Context, pp. 230-245, (Lexington, KY: The University of Kentucky Press, 1983) 232.

${ }^{10}$ This scene also reinforces the notion of narrative film over experimental film. As Willard composes himself after executing Kurtz and gathering up the manuscript, diegetic sound is replaced by silence and imposed synthesized music. This sound structure continues until Willard eschews assuming Kurtz's position as leader of these "tribes" people. At this point, Willard casts away the murder weapon, retaining the manuscript in his hand. As the weapon is cast away, diegetic sound resumes. This implies the return to standard narrative film structure as image matches sound. 